\title{
Economic Sanctions: Astute Policy or Just another Barrier to Free Trade?
}

\section{Charles A. Rarick}

Professor of International Business, College of Business, Purdue University Northwest, Hammond, IN 46323, USA

*E-mail for correspondence: crarick@pnw.edu

Received: Apr 14, 2016;

Accepted: Apr 25, 2016;

Published: July 30, 2016

Source of Support: Nil

No Conflict of Interest: Declared

\begin{abstract}
When mentioning free trade the topic of economic sanctions is seldom mentioned. However, governments of the developed world, especially the United States, have used economic sanctions as a foreign policy tool to compel other countries to change their behavior. The increasing use of economic sanctions as a form of foreign policy is not without cost, however, and that cost is borne by citizens of sanctioned countries and businesses who find international markets closed to them, either entirely or in part. In addition, consumers pay a price through less choice and higher prices. Economic sanctions are barriers to free trade and interfere with the free flow of goods and services. This case examines the current state of economic sanctions imposed by the United States and explores sanctions imposed on Cuba, Myanmar and Iran; three heavily sanctioned countries which recently have experienced a change in U.S. foreign policy action, yet still suffer from trade restrictions.
\end{abstract}

Keywords: economic sanctions, non-tariff barriers, trade theory

\section{INTRODUCTION}

Barriers to free trade are usually seen in the form of tariffs, or taxes on imports. Non-tariff barriers usually mentioned include quotas, subsidies, import/export licenses, and currency manipulation. A large barrier to free trade which is seldom mentioned includes the economic sanctions imposed mostly by developed countries as a form of foreign policy. Economic sanctions are almost universally applied by developed countries against developing countries. While the underlying intent may not be the same as other forms of trade restrictions, the effect of economic sanctions is to restrict trade.

The United States is one of the biggest promoters of free trade in the world, or at least on the surface this appears to be the case. The United States promotes free trade through a number of free trade agreements and recently has lobbied countries for the very significantTrans-Pacific Partnership (TPP) and the Transatlantic Trade and Investment agreements. At the same time, there are a number of countries which are offlimits for American business transactions. The government of the United States has imposed a number of economic sanctions on a number of countries and individuals as a tool of foreign policy. These actions reduce opportunities for American businesspeople and act as a barrier to free trade. While the list of countries that have some form of economic sanction imposed by the United States is long, three countries in particular have had significant trade and investment restrictions. Cuba, Myanmar (Burma), and Iran have been essentially closed for American business through economic sanctions. This case explores economic sanctions in general as a barrier to trade and more specifically explores the specific cases of these three countries.

\section{ECONOMIC SANCTIONS}

Trade restrictions have existed for hundreds of years with countries refusing to trade with others for a variety of reasons. President George Washington, in his farewell address to the nation, however, warned about trade restrictions and "entanglements" with other nations. Washington promoted trade with all countries and suggested that the role of government should be limited to the promotion of trade with other countries for the benefit of "merchants". Since the time of Washington the United States has taken a different path. President Woodrow Wilson's failed League of Nations proposed using trade boycotts as a means of controlling the behavior of other countries. In an effort to control Japanese aggression prior to World War II the United States imposed an oil embargo on Japan. The embargo did not stop the aggression and may in fact have fueled further aggression leading to the War.

The current proliferation of economic sanctions began in the 1980s when the United States established a grain embargo against the former Soviet Union in response to 
the U.S.S.R.s invasion of Afghanistan. While the sanctions were ineffective in that other countries rushed in to supply the grain not purchased from the United States, it did signal a political move that would result in an ever increasing application of this form of foreign policy. Economic sanctions against South Africa in 1986 due to its policy of Apartheid were imposed by the United States and other developed countries resulting in a reversal of the racist policy. The success of economic sanctions imposed on South Africa may have increased the perceived value of this tool; however, the use of sanctions grew with mixed success and sometimes unusual consequences. American world chess master, Bobby Fischer, was indicted in 1992 for violating economic sanctions for playing a chess match in the former Yugoslav federation. A warrant for Mr. Fischer's arrest was issued by U.S. officials. Facing a possible prison sentence of 10 years Fischer never returned to the United States. Economic sanctions imposed by the United States are extensive and far-reaching and violating these sanctions can result in punishment to American citizens and businesses, as well as foreign nationals and organizations.

Federal economic sanctions are administered by the U. S. Department of the Treasury through its Office of Foreign Assets Control (OFAC). Currently, comprehensive economic sanctions are imposed Cuba, Myanmar, Iran, Syria, North Korea, and Sudan. Less comprehensive sanctioned countries include Belarus, some Balkan states, Ivory Coast, Democratic Republic of the Congo, Iraq, Libya, Somalia, and Zimbabwe. In addition there are sanctions that involve diamond trading, narcotics trafficking, transnational crime organizations, terrorists, and weapons of mass destruction. Many countries are in one way or another included in trade and investment restrictions under Treasury Department and OFAC enforcement and these restrictions represent a significant barrier to free trade.

The OFAC also has created a list of people and organizations that American businesses are prohibited from engaging in international business transactions. The list is quite long and is referred to as Specially Designated National and Blocked Persons (SDN). The list as of April 2016 contained over 6,000 names of people and organizations and is over 900 pages long in a PDF format found on the U.S. Treasury Website. On the Website businesses can also find frequently asked questions (FAQs) concerning compliance with the staggering restrictions. There are over 200 FAQs and answers dealing with everything from penalties for dealing a SDN with a "weak alias" to how banks need to track corporate sponsored matching gifts to charities which may be prohibited. Attempting to understand and keep up with the regulations is a daunting task for American businesses.

While the list of sanctioned countries is long and the list of SDN's is even longer, three countries are profiled in this case to give a better understanding of the motives, details, costs, and possible benefits of economic sanctions. The United States has a long, and it could be argued, unproductive history of trade restrictions with Cuba. The more recent sanctions against Myanmar and Iran may be resulting in productive change in those countries, although it could be argued that the sanctions will in the end not really be effective in bringing about the changes sought.

\section{The Case of Cuba}

The Republic of Cuba has been a source of tension and conflict for over 50 years for the United States. Cuba was ceded along with other territories lost by Spain in the Spanish-American War in 1898. The war began with the Cuban struggle for independence from Spain. Cuba was granted its independence but developed an economic dependency on the United States. Over the years Cuba became a popular vacation spot for Americans and the American Mafia established gambling and other forms of entertainment on the island. Fidel Castro and his rebel band took power in 1959 by overthrowing the government of President Batista. At the time of the revolution, American businesses owned very significant parts of the Cuban economy. This was resented by many Cubans, especially Castro who nationalized private property, including that owned by Americans. In response, President Eisenhower imposed trade restrictions on Cuba.

In 1962 President Kennedy ordered a complete embargo on Cuba and virtually all trade and investment between the two countries was stopped. Cuba remains a developing country and its economic growth is hampered by its internal economic policies and the economic sanctions imposed by the United States. Per capita GDP in Cuba is $\$ 6,790$ (World Bank estimate). Fidel Castro turned over power to his brother, Raul, in 2006 and Raul has made some small economic reforms on the island. Political reform has not yet happened and seems unlikely in the near future. Economic prospects in Cuba recently have improved with the potential of large oil and gas reserves believed to be off the island. It has been estimated that between 5-20 billion barrels of oil are within Cuban coastal waters. American oil companies are prohibited from benefiting from this potentially large reserve. Due to economic sanctions the first rig for exploration was shipped half-way around the world from Singapore, even though the equipment and expertise could have been acquired much closer in the United States. If the oil riches prove to be as large as expected, Cuba can become a large consumer market. Over the past 50 years American businesses have lost out to other nations who have no such restrictions on doing business in Cuba. Many allies of the United States, including Canada, Spain, France, and Great Britain have been more than happy to do business with Cuba and capitalize on the opportunities closed to American firms. In 2016 President Obama began a process of normalizing 
relations between the United States and Cuba, yet with the exception of lifting some travel restrictions, all of the economic sanctions remained in place and would require Congressional action in order to be removed. After more than a half-century of trade restrictions imposed to change Cuba's leadership and governmental policy little progress has been made and American business opportunities remain uncertain.

\section{The Case of Myanmar}

Another country in which the United States imposed comprehensive sanctions against is Myanmar, better known in the U.S. by its former name, Burma. Burma, once under British control became independent from Great Britain after World War II. Burma held its first democratic election in 1951, but by 1962, ethnic conflict and internal rivalry resulted in a military coup. The military government nationalized businesses and proceeded along the road to "the Burmese way of socialism." In the 1980s, a democratic movement began in Myanmar, resulting in mass protests and what is believed to have been the death of thousands of citizens. Free elections were held in 1990, with the National League for Democracy winning a majority of the votes. The ruling military junta refused to accept the election results and ordered the house arrest of the party's leader, Aung San Suu Kyi. In addition to its disregard for democracy, the ruling junta also held a number of political prisoners, and was accused of violating basic human rights of its citizens. In response to the lack of democracy, and the civil rights violations in Myanmar, the U.S. Congress passed legislation; and the Executive Branch issued executive orders, essentially banning business in Myanmar for American companies. While the Myanmar government acted in ways inconsistent with good governance the country is not alone in having a government considered less than ideal. The U.S. imposes sanctions on Myanmar while it supports other nondemocratic regimes such as Saudi Arabia and China.

Economic sanctions aimed at the government of Myanmar resulted in closed factories and high unemployment for its citizens. Per capita GDP in Myanmar now stands at only $\$ 1,204$ (World Bank estimate) in a country rich in natural resources such as oil and gas, timber, tin, copper, zinc, and precious stones. While other countries imposed limited sanctions on Myanmar, the widespread sanctions imposed by the world's largest economy increased the suffering of the Burmese people. Losing the United States as a trading partner also increased economic exchange with China. Myanmar grew increasingly dependent on China for investment, and to the point where Chinese investment in key sectors of the economy have made the Burmese feel their country is becoming a satellite state of China.

In 2010 Aung San Suu Kyi was released from house arrest. Her release was seen as an effort by the rulers of Myanmar to engage with the West and move the country forward. With the release of Aung San Suu Kyi and her subsequent election to the Myanmar parliament in May of 2012, the Obama administration announced that the United States would be lifting some sanctions on the country. Lifting all of the economic sanctions would require Congressional action as some were created through federal statute. In 2015, Aung San Suu Kyi's political party, the National League for Democracy, won an overwhelming number of seats in Parliament; however, she is prohibited from becoming president of the country and instead was given a newly created role as State Counsellor. Myanmar could be seen as a success story in the use of economic sanctions. It could also be argued that the aging military junta that has ruled the country for so long was attempting to avoid a United Nations inquiry into their criminal violations of human rights. The aging junta members may have changed political direction and allowed for democratic rule, however, it remains to be seen how much control the military will possess as the democratic process moves forward and if the newly elected leaders can unite the ethnic division which has plagued the country for many years.

\section{The CASE OF IRAN}

The Islamic Republic of Iran and its 80 million citizens remain under heavy U.S. imposed economic sanctions even though an international agreement to lift sanctions relative to its nuclear program has been eased. Relations between the United States and Iran over the years have been volatile. When Prime Minister Mossadegh nationalized foreign oil interests in 1953 the United States and Britain helped to organize a coup and to return the son of the former Shah, Mohammad Reza Pahlavi, to power. The proWestern Shah enjoyed good relations with the United States until the 1979 revolution which replaced him with an Islamic Republic that was markedly anti-Western, with special hostilities towards the United States. Seizing the American Embassy and other U.S. interests created decades of hostility between the two countries.

A number of economic sanctions were placed on Iran by the United States and others. The most significant sanctions were imposed to prevent Iran from continuing to develop material capable of producing a nuclear weapon. Although heavily sanctioned, Iran was able to sell oil by transporting it to places such as Malaysia and transferring the tanker contents onto another ship. Iran also used financial intermediaries in order to avoid some of the financial sanctions imposed on the country. The sanctions on Iran's oil and financial sectors were eased in early 2016 allowing Iran, with the world's $4^{\text {th }}$ largest oil reserves, to sell its oil on the open market and gain access to the international financial system. In addition, Iran will receive approximately $\$ 100$ billion in frozen assets. In exchange Iran pledges to dismantle much of its nuclear program.The agreement easing sanctions has been heavily criticized as not insuring that Iran will discontinue its nuclear weapons ambitions. 
With a per capita GDP of $\$ 5,433$ (World Bank estimate), large oil reserves providing the potential for rising income, and much pent-up demand for Western products, Iran would appear to be a good market for American products and services. While European companies will have access to the Iran market, American firms will face essentially the same restrictions in doing business with Iran.

\section{High Price for American Business and Trade}

When considering the cost of economic sanctions it is necessary to consider the effectiveness of sanctions and the cost to the residents of the sanctioned countries. While there have been cases in which sanctions have resulted in governmental change, most notably in South Africa, most sanctions do not produce their intended outcomes. The effectiveness of economic sanctions has not been very good, and in cases where it does produce desired changes, it often takes a long time to bring about that change. In addition, economic sanctions often hurt the people the sanctions were intended to help by making their economic lives more difficult.

Concerning the cost of business opportunity, sanctioned countries represents a significant loss of business for American firms. Beginning with the ban on exporting grain to the Soviet Union in 1980 by President Carter, billions of dollars in loss opportunity have occurred. In addition to grain, prohibitions on the sale of heavy equipment and other industries to help build the Siberian pipeline cost even more. The pipeline was built by American competitors and Caterpillar lost its dominant position in Russia to its Japanese competitor.

In addition to direct costs of sanctions there are indirect costs such as missed opportunities and the costs of competitors from others countries establishing themselves in the sanctioned countries and shutting off potential business even after sanctions have ended. It could be argued that in a capitalist economy businesses stay in business through profitability and are victims of misguided foreign policy. Economic sanctions cost American businesses billions of dollars in lost profit every year, cost Americans jobs, and represent a significant barrier to free trade. Barriers to trade reduce global GDP potential by interfering with the comparative advantage that comes from free trade. The theory of comparative proposed by David Ricardo and absolute advantage theory of Adam Smith both suggest that free trade makes the world better off economically.

\section{The Case for Sanctions}

With the costs of economic sanctions to American business and the loss of jobs it is tempting to recommend that they simply be abolished as a form of foreign policy. There are of course problems with this approach. There are legitimate national security reasons for some sanctions. Selling North Koreans, Libyans, Syrians, or even the Chinese the latest in certain technology product lines may very well represent a danger to the national security of the United States.

It could be argued that the United States has a role to play in reducing evil in the world. The human tragedy experienced in West Africa in recent decades, which was funded by "blood diamonds", has little to compare in terms in its extreme brutality and human suffering. Economic sanctions and international cooperation that restricted trade with offending countries created a process that greatly reduced the funding sources for violent rebel groups in those African countries. Economic sanctions and world pressure brought an end to Apartheid in South Africa. Economic sanctions may finally be moving the brutal regime in Myanmar towards a more peaceful, democratic, and modern country. Even Iran seemed to feel the sting of multinational economic sanctions and signed an agreement which is purported to redirect its developing nuclear industry. While there are many costs that come with economic sanctions, and their effectiveness is certainly not always assured, there may be good reason to continue their use as a tool of American foreign policy. Widespread economic sanctions, however, could be viewed as restrictions on trade, and inconsistent with the free trade principles espoused by the United States and other developed countries.

\section{Discussion QuESTIONS}

- Sanctions would seem to violate World Trade Organization (WTO) free trade principles. Can economic sanctions be imposed without a penalty from the WTO? Explain.

- Are economic sanctions simply another form of a non-tariff trade barrier or is the situation more complex? Explain.

- Was President Washington correct in asserting that government policy should promote trade and not interfere in the internal affairs of other countries? Explain.

- Do the theories of absolute and comparative advantage still make sense? If so, how can one justify economic sanctions?

- Most economic sanctions are imposed by developed countries against less developed countries. Can it be argued that richer countries are treating poorer countries unfairly? Explain.

\section{REFERENCES}

Anonymous. (2016). Iran sanctions: What is expected next? Aljazeera, January 17.

Anonymous. (2016). Myanmar-China relations: High mountains, distant emperors. The Economist, April 23.

Bemis, J. (1934). Washington's farewell address.A foreign policy of independence. The American Historical Review, 39(2).

Emont, J. (2015). Can Myanmar's new government control its military? The New Yorker, November 9. 
Friedman, U. (2012). Smart sanctions: A short history. Foreign Policy, April.

https:/ / www.treasury.gov/resourcecenter/sanctions/Programs/Documents/cuba_faqs_new.p df. Accessed on April 21, 2016.

Labaton, S. (1992).Fischer is indicted over chess match. The New York Times, December 16.

Long, H. (2016). Why U.S. businesses could lose big in Iran. CNN Money, January 11.

Losman, D. (1998). Economic sanctions: An emerging business menace. Business Economics, 33 (2).

Myers, S. (2012). As relations warm with Myanmar, U.S. will ease trade restrictions. The New York Times, May 17.

Rainsford, S. (2012).Cuba oil: Offshore exploration brings hopes and fears. BBC News, February 1.
Rarick, C. (2006). Destroying a country in order to save it: The folly of economic sanctions against Myanmar. Economic Affairs, 26 (2).

Rarick, C. (2007). Economic sanctions: Failed foreign policy tool and cost to American business. Economic Affairs, 27 (3).

Rasmussen, S. (2016). How Babak Zanjani went from Iran's top sanctions buster to dead billionaire walking. Newsweek, March 14.

Sridharan, V. (2016). Aung San Suu Kyi pledges to amend juntawritten constitution and reach out to ethnic minorities. International Business Times, April 18.

Suddath, C. (2009). A brief history of U.S.-Cuba relations. Time, April 15.

Warrick, J. (2012). Iran's economic pain deepens as new nuclear talks begin. The Washington Post, June 16.

www.state.gov. Accessed on March 21, 2016.

www.treasury.gov. Accessed on April 12, 2016.

www.worldbank.org. Accessed on April 13, 2016.

$--0--$

NOTE: A Teaching Note is available upon request for verified university faculty. 


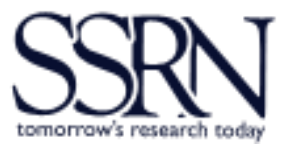

SOCIAL SCIENCE RESEARCH NETWORK

2171 Monroe Avenue, Suite 203, Rochester, NY 14618, USA

http://www.ssrn.com/en/

AJTP Link: http://www.ssrn.com/link/American-Journal-Trade-Policy.html 